Prepared for the U.S. Department of Energy under Contract DE-AC05-76RL01830

\title{
A Brief Literature Overview of Various Routes to Biorenewable Fuels from Lipids for the National Alliance for Advanced Biofuels and Bio-products (NAABB) Consortium
}

KO Albrecht RT Hallen

March 2011

Pacific Northwest

NATIONAL LABORATORY

Proudly Operated by Battelle Since 1965 


\title{
DISCLAIMER
}

This report was prepared as an account of work sponsored by an agency of the United States Government. Neither the United States Government nor any agency thereof, nor Battelle Memorial Institute, nor any of their employees, makes any warranty, express or implied, or assumes any legal liability or responsibility for the accuracy, completeness, or usefulness of any information, apparatus, product, or process disclosed, or represents that its use would not infringe privately owned rights. Reference herein to any specific commercial product, process, or service by trade name, trademark, manufacturer, or otherwise does not necessarily constitute or imply its endorsement, recommendation, or favoring by the United States Government or any agency thereof, or Battelle Memorial Institute. The views and opinions of authors expressed herein do not necessarily state or reflect those of the United States Government or any agency thereof.

\author{
PACIFIC NORTHWEST NATIONAL LABORATORY \\ operated by \\ BATTELLE \\ for the \\ UNITED STATES DEPARTMENT OF ENERGY \\ under Contract DE-AC05-76RL01830
}

Printed in the United States of America

Available to DOE and DOE contractors from the

Office of Scientific and Technical Information,

P.O. Box 62, Oak Ridge, TN 37831-0062;

ph: (865) 576-8401

fax: $(865) 576-5728$

email: reports@adonis.osti.gov

\footnotetext{
Available to the public from the National Technical Information Service, U.S. Department of Commerce, 5285 Port Royal Rd., Springfield, VA 22161 ph: (800) 553-6847 fax: $(703) 605-6900$

email: orders@ntis.fedworld.gov

online ordering: http://www.ntis.gov/ordering.htm
}

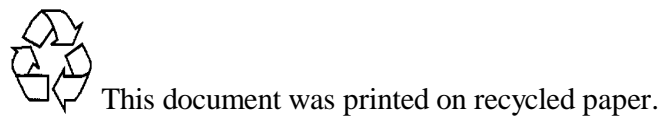




\subsection{Introduction}

Methods of producing renewable transportation fuels are currently the focus of numerous large research efforts across the globe. Renewable fuel produced from algal lipids is one aspect of this research that could have profound implications on future transportation fuel requirements. However, technical challenges remain in several areas of algal-lipid-based fuels. These challenges include the identification and development of robust and productive algal species as well as extraction methods to recover the produced lipids. Not the least of these technical challenges is the conversion of the algae lipids to fungible fuels. This brief literature review focuses primarily on state-of-the-art "downstream" applications of producing fuel from fats and lipids, which can be applied to ongoing research with algaederived lipids.

Algae lipids (oil) are similar to other oils in that three acyl groups are coupled to a glycerol "back bone." The acyl groups are typically 14-22 carbons in length and have varying degrees of unsaturation from 0 to 6 double bonds. ${ }^{1}$ The three acyl groups attached to the glycerol backbone are commonly referred to as triacyl glycerides, or TAGs. There are currently two major routes to producing diesel fuel from TAGs. First, the most common and commercially practiced method is to remove the acyl chains from the glycerol backbone using methanol as a co-reactant and a homogenous catalyst via a mechanism known as transesterification. Transesterification results in molecules known as fatty acid methyl esters, or FAMEs, which are widely used as biodiesel.

An alternate processing route for producing diesel fuel from algae-derived lipids is through deoxygenation. TAGs can be directly deoxygenated, or hydrolysis of the fatty acid chains could first be performed with subsequent deoxygenation of the fatty acids. FAMEs may also be deoxygenated. Deoxygenation can be performed through several different mechanisms. Hydrodeoxygenation is a mechanism that utilizes hydrogen to produce saturated alkanes and water as products. Hydrodeoxygenation can be applied to TAGs, FAMEs, and/or free fatty acids (FFAs). Catalytic decarboxylation of TAGs, FAMEs or FFAs can also be performed, resulting in oxygen removal through the production of $\mathrm{CO}_{2}$. The feed stock molecules can also be non-selectively cracked or pyrolyzed. Regardless of the mechanism, the goal of deoxygenation is to produce hydrocarbon chains without oxygen present. In contrast to FAMEs which contain oxygen present in the ester group, deoxygenated hydrocarbons are expected to be essentially oxygen free. 
For clarity, it is important to distinguish between the terms "biodiesel" and "renewable diesel." Knothe recently published a review with an excellent commentary on the usage of these terms. Knothe describes FAMEs as "biodiesel" and oxygen-free hydrocarbons produced by hydrotreating TAGs as "renewable diesel." Similar to Knothe, the current review will use the term biodiesel to describe FAMEs. In contrast to Knothe, renewable diesel will be used to describe all diesel-range deoxygenated hydrocarbons produced from TAGs, FAMEs or FFAs by any mechanism, including hydrotreating, selective catalytic decarboxylation, cracking or pyrolysis. Green diesel, which is another term that appears commonly in the literature, should be considered analogous to renewable diesel in the current review.

After the initial discussion of terminology, the review by Knothe proceeds into a discussion on the pros and cons of both biodiesel and renewable diesel. Smith et al. ${ }^{3}$ also recently published a review on different sources and technologies pertaining to biodiesel and renewable diesel. Other reviews that the authors have found particularly helpful include the discussion on biodiesel by Ma and Hanna, ${ }^{4}$ a review on various hydrotreating and cracking methods by Huber and Corma, ${ }^{5}$ and the more encompassing reviews by Lestari et al. ${ }^{6}$ and Kubickova and Kubicka. ${ }^{7}$ These reviews cover a large amount of published data in great detail and are invaluable to those working in the area of oil and lipid conversion to fuels.

\subsection{Biodiesel}

Biodiesel is commercially produced from TAG's with methanol added as a co-reactant and $\mathrm{NaOH}$ added as a homogenous basic catalyst. In the conventional process, the lipid feedstock must have very low FFA content because the basic $\mathrm{NaOH}$ will cause the FFAs to saponify into fatty acid salts (soap). Ma and Hanna ${ }^{4}$ reviewed the production of biodiesel with an emphasis on the transesterification mechanism. Meher et al. ${ }^{8}$ also reviewed the transesterification mechanism for the production of biodiesel. Knothe et al. ${ }^{9}$ published an overview of biodiesel with respect to economics, technical challenges and engine performance issues.

An alternative to the transesterification mechanism is the esterification mechanism, which can convert FFAs as well as TAGs to biodiesel. Lam et al. ${ }^{10}$ recently reviewed homogenous, heterogeneous and enzymatic catalysts capable of converting used cooking oil, which has a high concentration of FFAs, into biodiesel. Di Serio et al. ${ }^{11}$ reviewed both acidic and basic heterogeneous catalysts. Iyer ${ }^{12}$ recently applied for a patent for a process utilizing cationic and anionic exchange resins as acidic and basic catalysts, respectively. A single-step solid-acid-catalyzed process from feeds with high FFA concentrations was reported by Baig et al. ${ }^{13}$ State-of-the-art catalysts such as functionalized 
mesoporous silicas were reviewed by Mbaraka and Shanks ${ }^{14}$ and continue to be of interest as demonstrated by the recent publication by Ngo et al. ${ }^{15}$

\subsection{Renewable Diesel}

Renewable diesel produced via catalytic hydrotreating of various lipid feedstocks is a process that has recently been commercialized by several companies. The Neste Oil NExBTL process produces renewable diesel by hydrotreating vegetable oils or waste fats, resulting in a 40-80\% lifecycle reduction in $\mathrm{CO}_{2}$ depending on the feedstock. ${ }^{16}$ Neste Oil recently opened a plant in Singapore using NExBTL technology that will produce more than 800,000 tons per year of renewable diesel from feedstocks such as palm oil and waste animal fat. ${ }^{17}$

The UOP/Eni Ecofining ${ }^{18}$ process is based on the hydrotreating of TAGs and/or FFAs, which results in deoxygenation via hydrodeoxygenation and decarboxylation. ${ }^{19,20}$ After the hydrotreating step, an isomerization process is performed to produce an isoparaffin rich diesel fuel. The renewable diesel product produced by the Ecofining process (termed "green diesel" by the authors) was reported to be economically competitive with biodiesel based upon a life cycle analysis reported in a 2009 publciation. $^{21}$

Dyanmic Fuels, which is a joint venture between Syntroleum and Tyson Foods, recently opened a plant in Geismar, LA for the production of renewable diesel from non-food grade animal fats. ${ }^{22}$ The animal fat includes beef tallow, pork lard, chicken fat and greases. Syntroleum reported that the carbon footprint of the renewable diesel produced at the plant is $75 \%$ below petroleum diesel. The plant is designed to produce up to 75 million gallons of renewable fuel per year.

Valero also recently announced that a new plant at its St. Charles Refinery in Norco, LA will be utilized to convert used cooking oil and animal fat into renewable diesel via hydrogenation and isomerization processes. ${ }^{23}$ The fat and oil feedstocks will be supplied by Darling International, who is Valero's partner in the venture. The new plant is slated to begin construction in the second or third quarter of 2011.

Several other independent groups have also investigated hydrotreating various lipids and fats to produce fuels. Simacek et al. ${ }^{24}$ recently reported the utilization of hydrorefining NiMo/alumina catalysts to hydroprocess rapeseed oil. At a pressure of $7 \mathrm{MPa} \mathrm{H}_{2}$ and temperatures above $310^{\circ} \mathrm{C}$, the main products were $\mathrm{C}_{17}$ and $\mathrm{C}_{18}$ hydrocarbons. Many of the reports in the academic and patent literature use traditional hydrotreating catalysts such as sulfided CoMo or NiMo based catalysts. ${ }^{25-44}$ Hydrotreating 
lipid feedstocks in general has generated a large number of recent patents and patent applications. ${ }^{45-54}$ Of particular interest is a recent patent published by Day and Franklin ${ }^{55}$ on the catalytic hydroprocessing of microalgal oils.

More technical aspects on the kinetics and thermodynamics of the hydrotreating various feedstocks are also available in the open literature. ${ }^{56-59}$

Aatol et al. ${ }^{60}$ reported on the performance of diesel engines with fuels produced via hydrotreating vegetable oil at the SAE International conference in Chicago in 2008. More recently, Simacek et al. ${ }^{61}$ reported on the fuel properties of hydroprocessed rapeseed oil. Similarly, the fuel properties of a fuel produced by hydrocracking petroleum vacuum distillate containing rapeseed oil was evaluated by Simacek and Kubicka. ${ }^{62}$

Selective catalytic deoxygenation via a decarboxylation mechanism has been an active area of recent research. ${ }^{63-65}$ In contrast to the hydrodeoxygenation mechanism, decarboxylation does not require a stoichiometric level of $\mathrm{H}_{2}$ consumption to produce renewable diesel. Current state-of-the-art catalysts for selective catalytic deoxygenation typically utilize noble metal supported catalysts, with Pd being the most common. While TAGs ${ }^{66,67}$ and FAMEs ${ }^{66,68-72}$ have been studied, much of the effort to date on selective deoxygenation to produce fuels has been on FFA feedstocks. FFAs could be produced via the hydrolysis of TAGs to produce one mole of glycerol and three FFA chains. Maier et al. ${ }^{73}$ published an early account of the gas-phase decarboxylation of shorter chain $\left(\mathrm{C}_{7}\right.$ and $\left.\mathrm{C}_{8}\right)$ fatty acids over $\mathrm{Pd}$ and $\mathrm{Ni}$. More recently, the Murzin group at Abo Akademi in The Netherlands has led a substantial effort on the deoxygenation of FFAs to produce diesel fuel focusing primarily on Pd on carbon catalysts to produce renewable diesel. ${ }^{71,74-84}$

As evidenced by some reports, improvement in Pd-based catalysts in continuous operation may be necessary because some reports suggest they are hindered by rapid deactivation. Maki-Arvela et al. ${ }^{74}$ reported that the deactivation of a Pd catalyst while decarboxylating lauric acid may have been due to poisoning by the product gases $\left(\mathrm{CO}\right.$ and $\left.\mathrm{CO}_{2}\right)$ and/or coking. Currently, the best continuous conversion in the literature appears to be about $40 \%$ conversion of stearic acid to heptadecane after $92 \mathrm{hr}$ of time on stream at $360^{\circ} \mathrm{C}$ with a "commercial Pd/C catalyst" as reported by Lestari et al. ${ }^{76}$

FFAs may also be partially deoxygenated via ketonization over basic catalysts. Renz ${ }^{85}$ recently reviewed this process as it relates to several feeds. The ketonization reaction is a bimolecular process whereby one mole each of $\mathrm{CO}_{2}$ and water is rejected and a ketone is formed from the original fatty acid 
molecules. For example, two stearic acid molecules may react to form 1 mole of $\mathrm{CO}_{2}$ and $\mathrm{H}_{2} \mathrm{O}$, but the resulting ketone is a symmetrical $\mathrm{C}_{35}$ ketone. Thus, the resulting hydrocarbon is not completely deoxygenated. Additionally, the $C_{35}$ molecule would require further processing such as hydrocracking and isomerization to obtain a diesel-like fuel.

The non-selective removal of oxygen from fats and lipids via pyrolysis or cracking has also been studied. TAGs, ${ }^{5,-115}$ FAMEs, ${ }^{116-120}$ and FFAs ${ }^{121-123}$ have all been studied as feedstocks for cracking and pyrolysis reactions. Pyrolysis and cracking reactions have typically been studied on acidic materials, although alumina ${ }^{117,123}$ and basic ${ }^{91}$ catalysts such as $\mathrm{MgO}$ and $\mathrm{CaO}$, and even $\mathrm{Na}_{2} \mathrm{CO}_{3}{ }^{115}$ have also been studied. Cracking and pyrolysis reactions, which take place at elevated temperatures between $300-500^{\circ} \mathrm{C}$, typically result in a distribution of molecules after treatment with varying amounts of less desirable short chain hydrocarbons. Additionally, many of the reports focused on cracking and pyrolysis mechanisms are performed with the goal of producing a lower boiling range fuel such as gasoline because cracking reduces the chain length and, thus, increases the volatility of the produced fuels.

\subsection{Summary}

Algae-derived lipids hold vast potential as a sustainable source for transportation fuels, especially diesel. Biodiesel produced by transesterification or esterification reactions as well as renewable diesel produced by deoxygenation mechanisms are both promising methods for transforming the initial algallipid feedstocks into a source of fuel. All of the routes to algal-lipid derived fuel possess unique research challenges. Ensuring that these fuels provide maximum economic, environmental and political impact should continue to be a significant focus of work and collaboration in the future. 


\subsection{References}

1. Fisher, B. C.; Marchese, A. J.; Volckens, J.; Lee, T.; Collett, J. L. J., Measurement of Gaseous Particulate Emissions from Algae-Based Fatty Acid Methyl Esters. SAE International 2010, 2010-01-1523.

2. Knothe, G., Biodiesel and renewable diesel: A comparison. Progress in Energy and Combustion Science 2010, 36, (3), 364-373.

3. Smith, B.; Greenwell, H. C.; Whiting, A., Catalytic upgrading of tri-glycerides and fatty acids to transport biofuels. Energy \& Environmental Science 2009, 2, 262-271.

4. Ma, F.; Hanna, M. A., Biodiesel production: a review. Bioresource Technology 1999, 70, (1), 1-15.

5. Huber, George W.; Corma, A., Synergies between Bio- and Oil Refineries for the Production of Fuels from Biomass. Angewandte Chemie International Edition 2007, 46, (38), 7184-7201.

6. Lestari , S.; Mäki-Arvela, P.; Beltramini, J.; Lu, G. Q. M.; Murzin, Dmitry Y., Transforming Triglycerides and Fatty Acids into Biofuels. ChemSusChem 2009, 2, (12), 1109-1119.

7. Kubičková, I.; Kubička, D., Utilization of Triglycerides and Related Feedstocks for Production of Clean Hydrocarbon Fuels and Petrochemicals: A Review. Waste and Biomass Valorization 2010, 1-16.

8. Meher, L. C.; Vidya Sagar, D.; Naik, S. N., Technical aspects of biodiesel production by transesterification--a review. Renewable and Sustainable Energy Reviews 2006, 10, (3), 248-268.

9. Knothe, G.; Dunn, R. O.; Bagby, M. O. In Biodiesel: The Use of Vegetable Oils and Their Derivatives as Alternative Diesel Fuels, Fuels and Chemicals from Biomass, 1997; Saha, B. C.; Woodward, J., Eds. American Chemical Society: 1997; pp 172-208.

10. Lam, M. K.; Lee, K. T.; Mohamed, A. R., Homogeneous, heterogeneous and enzymatic catalysis for transesterification of high free fatty acid oil (waste cooking oil) to biodiesel: A review. Biotechnology Advances 2010, 28, (4), 500-518.

11. Di Serio, M.; Tesser, R.; Pengmei, L.; Santacesaria, E., Heterogeneous Catalysts for Biodiesel Production. Energy \& Fuels 2007, 22, (1), 207-217.

12. Iyer, S. R. Systems and Methods for Esterification and Transesterification of Fats and Oils. US20100202933A1, 20100419, 2010.

13. Baig, A.; Ng, F. T. T., A Single-Step Solid Acid-Catalyzed Process for the Production of Biodiesel from High Free Fatty Acid Feedstocksâ€ Energy \& Fuels 2010, 24, (9), 4712-4720.

14. Mbaraka, I. K.; Shanks, B. H., Conversion of Oils and Fats Using Advanced Mesoporous Heterogeneous Catalysts. Journal of the American Oil Chemists' Society 2006, 83, (2), 79-91. 
15. Ngo, H.; Zafiropoulos, N.; Foglia, T.; Samulski, E.; Lin, W., Mesoporous Silica-Supported Diarylammonium Catalysts for Esterification of Free Fatty Acids in Greases. Journal of the American Oil Chemists' Society 2010, 87, (4), 445-452.

16. Neste Oil. NExBTL Diesel http://www.nesteoil.com/default.asp?path=1,41,11991,12243,12335. Last accessed March 23, 2011

17. United Press International. Singapore opens renewable diesel plant. http://www.upi.com/Science News/Resource-Wars/2011/03/09/Singapore-opens-renewable-dieselplant/UPI-74561299678336/. Last accessed March 23, 2011.

18. UOP. Green Diesel. http://www.uop.com/processing-solutions/biofuels/green-diesel/. Last accessed March 23, 2011

19. Kalnes, T.; Marker, T.; Shonnard, D. R., Green diesel: a second generation biofuel. International Journal of Chemical Reactor Engineering 2007, 5, No pp given.

20. Petri, J. A.; Marker, T. L. Production of diesel fuel from biorenewable feedstocks. US7511181B2, $20080225,2009$.

21. Kalnes, T. N.; Koers, K. P.; Marker, T.; Shonnard, D. R., A technoeconomic and environmental life cycle comparison of green diesel to biodiesel and syndiesel. Environmental Progress \& Sustainable Energy 2009, 28, (1), 111-120.

22. Evnvironmental Leader. Tyson Foods, Syntroleum Partner to Turn Grease into Fuel. http://www.environmentalleader.com/2010/11/09/tyson-foods-syntroleum-partner-to-turn-greaseinto-fuel/ Last accessed March 23, 2010

23. New Orleans Net. New renewable diesel plant headed to Norco with federal backing. http://www.nola.com/politics/index.ssf/2011/01/new biodiesel plant headed to.html. Last accessed March 23, 2011

24. Simácek, P.; Kubicka, D.; Sebor, G.; Pospísil, M., Hydroprocessed rapeseed oil as a source of hydrocarbon-based biodiesel. Fuel 2009, 88, (3), 456-460.

25. Craig, W. K.; Soveran, D. W. Production of hydrocarbons with a relatively high cetane rating. US4992605A, 19890127, 1991.

26. Dindi, H.; Sengupta, S. K.; Gonzon, A. F. Catalytic Process for Converting Renewable Resources into Paraffins for Use as Diesel Blending Stocks. US20080308457A1, 20080613, 2008.

27. Dindi, H.; Sengupta, S. K.; Gonzon, A. F.; Corbin, D. R. Catalytic Process for Converting Renewable Resources into Paraffins for Use as Diesel Blending Stocks. US20080308458A1, 20080613, 2008.

28. Dindi, H.; Sengupta, S. K.; Gonzon, A. F.; Corbin, D. R. Catalytic Process for Converting Renewable Resources into Paraffins for Use as Diesel Blending Stocks WO2008157465A2, 20080616, 2008. 
29. Jakkula, J.; Niemi, V.; Nikkonen, J.; Purola, V. M.; Myllyoja, J.; Aalto, P.; Lehtonen, J.; Alopaeus, V. Process for producing a hydrocarbon component of biological origin. US7232935B2, 20030905, 2007.

30. Koivusalmi, E.; Jakkula, J. Process for the Manufacture of Hydrocarbons. WO2007068798A3, 20061212, 2007.

31. Koivusalmi, E.; Jakkula, J. Catalytic process for the manufacture of branched and saturated hydrocarbons from (un)saturated fatty acid and fatty acid esters. 2006-637176 2007135669, 20061212., 2007.

32. Koivusalmi, E.; Jakkula, J. Process for the Manufacture of Hydrocarbons. US20090062578A1, 20081104, 2009.

33. Koivusalmi, E.; Kilpelainen, I.; Karhunen, P.; Matikainen, J. Saturated hydrocarbon base oils prepared from renewable resources by oligomerization and hydrodeoxygenation. 2006-637159 2007131579, 20061212., 2007.

34. Koivusalmi, E.; Myllyoja, J.; Matikainen, J. Process for Producing a Saturated Hydrocarbon. WO2007068800A3, 20061212, 2006.

35. Kubička, D.; Bejblová, M.; Vlk, J., Conversion of Vegetable Oils into Hydrocarbons over CoMo/MCM-41 Catalysts. Topics in Catalysis 2010, 53, (3), 168-178.

36. Kubicka, D.; Kaluza, L., Deoxygenation of vegetable oils over sulfided Ni, Mo and NiMo catalysts. Applied Catalysis A: General 2010, 372, (2), 199-208.

37. Kubička, D.; Šimáček, P.; Žilková, N., Transformation of Vegetable Oils into Hydrocarbons over Mesoporous-Alumina-Supported CoMo Catalysts. Topics in Catalysis 2009, 52, (1), 161-168.

38. Laurent, E.; Delmon, B., Study of the hydrodeoxygenation of carbonyl, car\&\#9744;ylic and guaiacyl groups over sulfided CoMo/[gamma]-Al2O3 and NiMo/[gamma]-Al2O3 catalysts: I. Catalytic reaction schemes. Applied Catalysis A: General 1994, 109, (1), 77-96.

39. Sebos, I.; Matsoukas, A.; Apostolopoulos, V.; Papayannakos, N., Catalytic hydroprocessing of cottonseed oil in petroleum diesel mixtures for production of renewable diesel. Fuel 2009, 88, (1), 145149.

40. Senol, O. I.; Viljava, T. R.; Krause, A. O. I., Hydrodeoxygenation of methyl esters on sulphided $\mathrm{NiMo/[gamma]-Al2O3} \mathrm{and} \mathrm{CoMo/[gamma]-Al2O3} \mathrm{catalysts.} \mathrm{Catalysis} \mathrm{Today} \mathrm{2005,} \mathrm{100,} \mathrm{(3-4),} \mathrm{331-335.}$

41. Senol, O. I.; Viljava, T. R.; Krause, A. O. I., Hydrodeoxygenation of aliphatic esters on sulphided

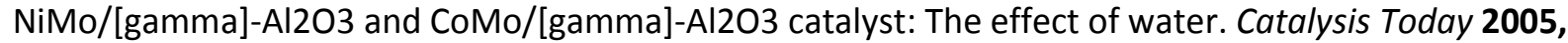
106, (1-4), 186-189.

42. Senol, O. I.; Viljava, T. R.; Krause, A. O. I., Effect of sulphiding agents on the hydrodeoxygenation of aliphatic esters on sulphided catalysts. Applied Catalysis A: General 2007, 326, (2), 236-244. 
43. da Rocha Filho, G. N.; Brodzki, D.; Djéga-Mariadassou, G., Formation of alkanes, alkylcycloalkanes and alkylbenzenes during the catalytic hydrocracking of vegetable oils. Fuel 1993, 72 , (4), 543-549.

44. Gusmão, J.; Brodzki, D.; Djéga-Mariadassou, G.; Frety, R., Utilization of vegetable oils as an alternative source for diesel-type fuel: hydrocracking on reduced $\mathrm{Ni} / \mathrm{SiO} 2$ and sulphided $\mathrm{Ni}$ Mo/[gamma]-Al2O3. Catalysis Today 1989, 5, (4), 533-544.

45. Brady, J. P.; Kalnes, T. N.; Marker, T. L. Production of Diesel Fuel from Biorenewable Feedstocks with Selective Separation of Converted Oxygen. US20090077868A1, 20080818, 2009.

46. Herskowitz, M.; Landau, M.; Reizner, I.; Kaliya, M. Production of diesel fuel from vegetable and animal oils. US20060207166A1, 20060320, 2006.

47. Marker, T. L.; Kokayeff, P.; Faraci, G.; Baldiraghi, F. Production of Diesel Fuel from Renewable Feedstocks with Reduced Hydrogen Consumption. US20090077867A1, 20080818, 2009.

48. Myllyoja, J.; Aalto, P.; Harlin, E. Process for the manufacture of diesel range hydrocarbons. EP1741767A1, 20050704, 2005.

49. Myllyoja, J.; Aalto, P.; Harlin, E. Process for the Manufacture of Diesel Range Hydrocarbons. WO2007003708A1, 20060629, 2006.

50. Myllyoja, J.; Aalto, P.; Savolainen, P.; Grönqvist, J.; Purola, V.-M.; Alopaeus, V. Process for the manufacture of diesel range hydrocarbons. EP1741768A1, 20050704, 2005.

51. Myllyoja, J.; Aalto, P.; Savolainen, P.; Purola, V. M.; Alopaeus, V.; Gronqvist, J. Process for the manufacture of diesel range hydrocarbons. US20070010682A1, 20060630, 2006.

52. Myllyoja, J.; Jakkula, J.; Aalto, P.; Koivusalmi, E.; Moilanen, J.; Selin, J.-F. Process ofr Producing a Hydrocarbon Component. WO2007068795A1, 20061212, 2007.

53. Myllyoja, J.; Jakkula, J.; Aalto, P.; Koivusalmi, E.; Selin, J.-F.; Moilanen, J. Process for Producing a Hydrocarbon Component. US20090247799A1, 20090430, 2009.

54. Yao, J.; Sughrue, I. I. E. L.; Cross, J. B.; Kimble, J. B.; Hsing, H.-H.; Johnson, M. M.; Ghonasgi, D. B. Process for converting triglycerides to hydrocarbons. US7550634B2, 20060130, 2009.

55. Day, A. G.; Franklin, S. Hydroprocessing Microalgal Oils. US20100170144A1, 20091218, 2010.

56. Boda, L.; Onyestyák, G.; Solt, H.; Lónyi, F.; Valyon, J.; Thernesz, A., Catalytic hydroconversion of tricaprylin and caprylic acid as model reaction for biofuel production from triglycerides. Applied Catalysis A: General 2010, 374, (1-2), 158-169.

57. Donnis, B.; Egeberg, R.; Blom, P.; Knudsen, K., Hydroprocessing of Bio-Oils and Oxygenates to Hydrocarbons. Understanding the Reaction Routes. Topics in Catalysis 2009, 52, (3), 229-240. 
58. Ryymin, E.-M.; Honkela, M. L.; Viljava, T.-R.; Krause, A. O. I., Insight to sulfur species in the hydrodeoxygenation of aliphatic esters over sulfided NiMo/[gamma]-Al2O3 catalyst. Applied Catalysis A: General 2009, 358, (1), 42-48.

59. Furimsky, E., Catalytic hydrodeoxygenation. Applied Catalysis A: General 2000, 199, (2), 147-190.

60. Aatola, H.; Larmi, M.; Sarjovaara, T.; Mikkonen, S., Hydrotreated Vegetable Oil (HVO) as a Renewable Diesel Fuel: Trade-off between NOx, Particulate Emission, and Fuel Consumption of a Heavy Duty Engine. In SAE International, SAE: Chicago, IL, 2008.

61. Simácek, P.; Kubicka, D.; Sebor, G.; Pospísil, M., Fuel properties of hydroprocessed rapeseed oil. Fuel 2010, 89, (3), 611-615.

62. Simácek, P.; Kubicka, D., Hydrocracking of petroleum vacuum distillate containing rapeseed oil: Evaluation of diesel fuel. Fuel 2010, 89, (7), 1508-1513.

63. Ping, E. W.; Wallace, R.; Pierson, J.; Fuller, T. F.; Jones, C. W., Highly dispersed palladium nanoparticles on ultra-porous silica mesocellular foam for the catalytic decarboxylation of stearic acid. Microporous and Mesoporous Materials 2010, 132, (1-2), 174-180.

64. Immer, J. G.; Kelly, M. J.; Lamb, H. H., Catalytic reaction pathways in liquid-phase deoxygenation of C18 free fatty acids. Applied Catalysis A: General 2010, 375, (1), 134-139.

65. Roberts, W. L.; Lamb, H. H.; Stikeleather, L. F.; Turner, T. L. Process for Conversion of Biomass to Fuel. US20090069610A1, 20071130, 2009.

66. Kubickova, I.; Snare, M.; Eranen, K.; Maki-Arvela, P.; Murzin, D. Y., Hydrocarbons for diesel fuel via decarboxylation of vegetable oils. Catalysis Today 2005, 106, 197-200.

67. Morgan, T.; Grubb, D.; Santillan-Jimenez, E.; Crocker, M., Conversion of Triglycerides to Hydrocarbons Over Supported Metal Catalysts. Topics in Catalysis 2010, 53, (11), 820-829.

68. Do, P.; Chiappero, M.; Lobban, L.; Resasco, D., Catalytic Deoxygenation of Methyl-Octanoate and Methyl-Stearate on Pt/AI2O3. Catalysis Letters 2009, 130, (1), 9-18.

69. Han, J.; Sun, H.; Ding, Y.; Lou, H.; Zheng, X., Palladium-catalyzed decarboxylation of higher aliphatic esters: Towards a new protocol to the second generation biodiesel production. Green Chemistry 2010, 12, (3), 463-467.

70. Han, J.; Sun, H.; Duan, J.; Ding, Y.; Lou, H.; Zheng, X., Palladium-Catalyzed Transformation of Renewable Oils into Diesel Components. Advanced Synthesis \& Catalysis 2010, 352, (11-12), 1805-1809.

71. Maki-Arvela, P.; Kubickova, I.; Snare, M.; Eranen, K.; Murzin, D. Y., Catalytic deoxygenation of fatty acids and their derivatives. Energy \& Fuels 2007, 21, (1), 30-41.

72. Snare, M.; Kubickova, I.; Maki-Arvela, P.; Eranen, K.; Murzin, D. Y., Continuous deoxygenation of ethyl stearate: a model reaction for production of diesel fuel hydrocarbons. Chemical Industries (Boca Raton, FL, United States) 2007, 115, (Catalysis of Organic Reactions), 415-425. 
73. Maier, W. F.; Roth, W.; Thies, I.; Schleyer, P. V., Hydrogenolysis .4. Gas-Phase Decarboxylation of Carboxylic-Acids. Chemische Berichte-Recueil 1982, 115, (2), 808-812.

74. Maki-Arvela, P.; Snare, M.; Eranen, K.; Myllyoja, J.; Murzin, D. Y., Continuous decarboxylation of lauric acid over Pd/C catalyst. Fuel 2008, 87, (17-18), 3543-3549.

75. Bernas, H.; Eränen, K.; Simakova, I.; Leino, A.-R.; Kordás, K.; Myllyoja, J.; Mäki-Arvela, P.; Salmi, T.; Murzin, D. Y., Deoxygenation of dodecanoic acid under inert atmosphere. Fuel 2010, 89, (8), 20332039.

76. Lestari, S.; Mal`ki-Arvela, P. i.; Bernas, H.; Simakova, O.; Sjol`holm, R.; Beltramini, J.; Lu, G. Q. M.; Myllyoja, J.; Simakova, I.; Murzin, D. Y., Catalytic Deoxygenation of Stearic Acid in a Continuous Reactor over a Mesoporous Carbon-Supported Pd Catalyst. Energy \& Fuels 2009, 23, (8), 3842-3845.

77. Lestari, S.; Mäki-Arvela, P.; Eränen, K.; Beltramini, J.; Max Lu, G.; Murzin, D. Y., Diesel-like Hydrocarbons from Catalytic Deoxygenation of Stearic Acid over Supported Pd Nanoparticles on SBA-15 Catalysts. Catalysis Letters 2010, 134, (3), 250-257.

78. Lestari, S.; Mäki-Arvela, P.; Simakova, I.; Beltramini, J.; Lu, G.; Murzin, D., Catalytic Deoxygenation of Stearic Acid and Palmitic Acid in Semibatch Mode. Catalysis Letters 2009, 130, (1), 4851.

79. Lestari, S.; Simakova, I.; Tokarev, A.; Maki-Arvela, P.; Eranen, K.; Murzin, D. Y., Synthesis of Biodiesel via Deoxygenation of Stearic Acid over Supported Pd/C Catalyst. Catal. Lett. 2008, 122, (3-4), 247-251.

80. Snare, M.; Kubickova, I.; Maki-Arvela, P.; Chichova, D.; Eranen, K.; Murzin, D. Y., Catalytic deoxygenation of unsaturated renewable feedstocks for production of diesel fuel hydrocarbons. Fuel 2008, 87, (6), 933-945.

81. Snare, M.; Kubickova, I.; Maki-Arvela, P.; Eranen, K.; Murzin, D. Y., Heterogeneous catalytic deoxygenation of stearic acid for production of biodiesel. Industrial \& Engineering Chemistry Research 2006, 45, (16), 5708-5715.

82. Murzin, D. Y.; Kubickova, I.; Snare, M.; Mäki Arvela, P.; Myllyoja, J. Method for the manufacture of hydrocarbons. EP1681337A1, 20050114, 2005.

83. Murzin, D. Y.; Kubickova, I.; SnÅRe, M.; MÄKi Arvela, P.; Myllyoja, J. Method for the Manufacture of Hydrocarbons. WO2006075057A3, 20060116, 2006.

84. Murzin, D. Y.; Kubickova, I.; Snåre, M.; Mäki-Arvela, P.; Myllyoja, J. Method for the manufacture of hydrocarbons. US7491858B2, 20060117, 2009.

85. Renz, M., Ketonization of Carboxylic Acids by Decarboxylation: Mechanism and Scope. European Journal of Organic Chemistry 2005, (6), 979-988. 
86. Benson, T. J.; Hernandez, R.; French, W. T.; Alley, E. G.; Holmes, W. E., Elucidation of the catalytic cracking pathway for unsaturated mono-, di-, and triacylglycerides on solid acid catalysts. Journal of Molecular Catalysis A: Chemical 2009, 303, (1-2), 117-123.

87. Charusiri, W.; Vitidsant, T., Kinetic Study of Used Vegetable Oil to Liquid Fuels over Sulfated Zirconia. Energy \& Fuels 2005, 19, (5), 1783-1789.

88. Charusiri, W.; Yongchareon, W.; Vitidsant, T., Conversion of used vegetable oils to liquid fuels and chemicals over HZSM-5, sulfated zirconia and hybrid catalysts. Korean Journal of Chemical Engineering 2006, 23, (3), 349-355.

89. Chow, P. W. Production of synthetic crude petroleum. US5233109A, 19901105, 1993.

90. Haag, W. O.; Rodewald, P. G.; Weisz, P. B. Conversion of biological material to liquid fuels. GB2039943A, 19791214, 1979.

91. Idem, R. O.; Katikaneni, S. P. R.; Bakhshi, N. N., Catalytic conversion of canola oil to fuels and chemicals: Roles of catalyst acidity, basicity and shape selectivity on product distribution. Fuel Processing Technology 1997, 51, (1-2), 101-125.

92. Indian Space Res, O. R. G. Production of Hydrocarbon by Thermolysis of Vegetable Oils. GB1524781A, 19770124, 1977.

93. Katikaneni, S.; Adjaye, J.; Idem, R.; Bakhshi, N., Performance studies of various cracking catalysts in the conversion of canola oil to fuels and chemicals in a fluidized-bed reactor. Journal of the American Oil Chemists' Society 1998, 75, (3), 381-391.

94. Katikaneni, S. P. R.; Adjaye, J. D.; Bakhshi, N. N., Performance of Aluminophosphate Molecular Sieve Catalysts for the Production of Hydrocarbons from Wood-Derived and Vegetable Oils. Energy \& Fuels 1995, 9, (6), 1065-1078.

95. Katikaneni, S. P. R.; Adjaye, J. D.; Bakhshi, N. N., Studies on the Catalytic Conversion of Canola Oil to Hydrocarbons: Influence of Hybrid Catalysts and Steam. Energy \& Fuels 1995, 9, (4), 599-609.

96. Katikaneni, S. P. R.; Adjaye, J. D.; Idem, R. O.; Bakhshi, N. N., Catalytic Conversion of Canola Oil over Potassium-Impregnated HZSM-5 Catalysts: C2â^'C4 Olefin Production and Model Reaction Studies. Industrial \& Engineering Chemistry Research 1996, 35, (10), 3332-3346.

97. Kloprogge, J. T.; Duong, L. V.; Frost, R. L., A review of the synthesis and characterisation of pillared clays and related porous materials for cracking of vegetable oils to produce biofuels.

Environmental Geology 2005, 47, (7), 967-981.

98. Ooi, Y.-S.; Zakaria, R.; Mohamed, A. R.; Bhatia, S., Catalytic Cracking of Used Palm Oil and Palm Oil Fatty Acids Mixture for the Production of Liquid Fuel:â€\%o Kinetic Modeling. Energy \& Fuels 2004, 18, (5), 1555-1561.

99. Pinho, A. D. R.; Silva, M.; Da Silva Neto, A. P.; Cabral, J. A. R. Catalytic cracking process for the production of diesel from vegetable oils. US7540952B2, 20060622, 2009. 
100. Rao, K. V. C. Hydrocarbons by thermolysis of vegetable oils. 77-773544 4102938, 19770302., 1978.

101. Twaiq, F. A.; Mohamed, A. R.; Bhatia, S., Liquid hydrocarbon fuels from palm oil by catalytic cracking over aluminosilicate mesoporous catalysts with various $\mathrm{Si} / \mathrm{Al}$ ratios. Microporous and Mesoporous Materials 2003, 64, (1-3), 95-107.

102. Twaiq, F. A.; Zabidi, N. A. M.; Bhatia, S., Catalytic Conversion of Palm Oil to Hydrocarbons: Performance of Various Zeolite Catalysts. Industrial \& Engineering Chemistry Research 1999, 38, (9), 3230-3237.

103. Twaiq, F. A.; Zabidi, N. A. M.; Mohamed, A. R.; Bhatia, S., Catalytic conversion of palm oil over mesoporous aluminosilicate MCM-41 for the production of liquid hydrocarbon fuels. Fuel Processing Technology 2003, 84, (1-3), 105-120.

104. Twaiq, F. A. A.; Mohamad, A. R.; Bhatia, S., Performance of composite catalysts in palm oil cracking for the production of liquid fuels and chemicals. Fuel Processing Technology 2004, 85, (11), $1283-1300$.

105. Weisz, P. B.; Haag, W. O.; Rodewald, P. G., Catalytic procution of high-grade fuel (gasoline) from biomass compounds by shape-selective catalysis. Science 1979, 206, 57-58.

106. Alencar, J. W.; Alves, P. B.; Craveiro, A. A., Pyrolysis of tropical vegetable oils. Journal of Agricultural and Food Chemistry 1983, 31, (6), 1268-1270.

107. Cinquemani, C.; Heil, V.; Jakob, J.; Weber, A. Process for converting of raw materials and waste materials containing oil or fat in a composition containing hydrocarbons. EP1489157A1, 20040615, 2004.

108. Dos Anjos, J. S.; De Araujo Gonzalez, W.; Lam, Y. L.; Frety, R., Catalytic decomposition of vegetable oil. Applied Catalysis 1983, 5, (3), 299-308.

109. Idem, R. O.; Katikaneni, S. P. R.; Bakhshi, N. N., Thermal Cracking of Canola Oil: Reaction Products in the Presence and Absence of Steam. Energy \& Fuels 1996, 10, (6), 1150-1162.

110. Lima, D. G.; Soares, V. C. D.; Ribeiro, E. B.; Carvalho, D. A.; Cardoso, É. C. V.; Rassi, F. C.; Mundim, K. C.; Rubim, J. C.; Suarez, P. A. Z., Diesel-like fuel obtained by pyrolysis of vegetable oils. Journal of Analytical and Applied Pyrolysis 2004, 71, (2), 987-996.

111. Schwab, A. W.; Dykstra, G. J.; Selke, E.; Sorenson, S. C.; Pryde, E. H., Diesel Fuel from Thermal Decomposition of Soybean Oil. Journal of the American Oil Chemists Society 1988, 65, (11), 1781-1786.

112. Vonghia, E.; Boocock, D. G. B.; Konar, S. K.; Leung, A., Pathways for the Deoxygenation of Triglycerides to Aliphatic-Hydrocarbons over Activated Alumina. Energy \& Fuels 1995, 9, (6), 1090-1096. 
113. Wiggers, V. R.; Meier, H. F.; Wisniewski Jr, A.; Chivanga Barros, A. A.; Wolf Maciel, M. R., Biofuels from continuous fast pyrolysis of soybean oil: A pilot plant study. Bioresource Technology 2009, 100, (24), 6570-6577.

114. Wiggers, V. R.; Wisniewski Jr, A.; Madureira, L. A. S.; Barros, A. A. C.; Meier, H. F., Biofuels from waste fish oil pyrolysis: Continuous production in a pilot plant. Fuel 2009, 88, (11), 2135-2141.

115. Zaher, F. A.; Taman, A. R., Thermally Decomposed Cottonseed Oil as a Diesel Engine Fuel. Energy Sources 1993, 15, 499-504.

116. Billaud, F.; Dominguez, V.; Broutin, P.; Busson, C., Production of Hydrocarbons by Pyrolysis of Methyl Esters from Rapeseed Oil. Journal of the American Oil Chemists Society 1995, 72, (10), 11491154.

117. Boocock, D. G. B.; Konar, S. K.; Glaser, G., The Formation of Petrodiesel by the Pyrolysis of Fatty Acid Methyl Esters over Activated Alumina. In Progress in Thermochemical Biomass Conversion, Bridgwater, A. V., Ed. Blackwell Publishing: 2001; pp 1517-1524.

118. Danuthai, T.; Jongpatiwut, S.; Rirksomboon, T.; Osuwan, S.; Resasco, D., Conversion of Methylesters to Hydrocarbons Over Zn-Modified H-ZSM-5 Zeolite Catalyst. Catalysis Letters 2009, 132, (1), 197-204.

119. Danuthai, T.; Jongpatiwut, S.; Rirksomboon, T.; Osuwan, S.; Resasco, D. E., Conversion of methylesters to hydrocarbons over an H-ZSM5 zeolite catalyst. Applied Catalysis A: General 2009, 361, (1-2), 99-105.

120. Sooknoi, T.; Danuthai, T.; Lobban, L. L.; Mallinson, R. G.; Resasco, D. E., Deoxygenation of methyl esters over CsNaX. Journal of Catalysis 2008, 258, (1), 199-209.

121. Ooi, Y.-S.; Zakaria, R.; Mohamed, A. R.; Bhatia, S., Catalytic conversion of palm oil-based fatty acid mixture to liquid fuel. Biomass and Bioenergy 2004, 27, (5), 477-484.

122. Ooi, Y.-S.; Zakaria, R.; Mohamed, A. R.; Bhatia, S., Catalytic Conversion of Fatty Acids Mixture to Liquid Fuel and Chemicals over Composite Microporous/Mesoporous Catalysts. Energy \& Fuels 2005, 19, (3), 736-743.

123. Leung, A.; Boocock, D. G. B.; Konar, S. K., Pathway for the Catalytic Conversion of Carboxylic Acids to Hydrocarbons over Activated Alumina. Energy \& Fuels 1995, 9, (5), 913-920. 